\title{
Pengaruh Penggunaan Augmented Reality pada Pembelajaran Sistem Saluran Pernapasan dan Sistem Saluran Pencernaan pada tubuh manusia
}

\author{
Rico Fiyan Hady, Teknologi Informasi Institut Sains dan Teknologi Terpadu Surabaya (iSTTS), \\ Hendrawan Armanto, Teknik Informatika Institut Sains dan Teknologi Terpadu Surabaya (iSTTS).
}

\begin{abstract}
Abstrak-Abstrak dituliskan Augmented Reality (AR) merupakan peluang baru untuk mempermudah kegiatan manusia dalam mengilustrasikan sesuatu. Karena pada dasarnya konsep AR adalah menampilkan objek grafis menjadi tampak nyata seolah ada dihadapan kita. Dalam segi pendidikan hal ini akan sangat berpengaruh mengingat konsep dari AR itu sendiri. Aplikasi ini akan mempermudah interaksi dua arah mengenai materi yang sedang disampaikan khususnya dalam jenjang sekolah dasar. Peserta didik seolah akan melihat objek yang sedang diajarkan berada didepan mereka. Hal ini membuat peserta didik dapat mengerti secara komplek dan terstruktur mengenai sistem pencernaan dan sistem pernapasan pada tubuh manusia dengan hanya menggunakan smartphone dan sebuah gambar sebagai marker. Hasil penelitian disalah satu sekolah mengungkap hasil belajar siswa dengan menggunakan metode pembelajaran AR akan meningkatkan pemahaman peserta didik dalam mengenal organ sesuai dengan kuisoner yang sudah diberikan sebesar 36\%. Aplikasi ini berhasil membantu belajar peserta didik untuk memperlajari sistem pernapasan dan sistem perncernaan pada tubuh manusia dengan menggunakan teknologi Augmented Reality (AR).
\end{abstract}

Kata Kunci-Augmentend Reality, Annova, Sistem Pencernaan, Sistem Pernapasan, Pembelajaran

\section{PENDAhUluan}

$\mathrm{M}$ edia pendidikan sangat diperlukan sebagai perantara penyampai pesan, guna meminimalkan kegagalan selama proses komunikasi berlangsung. Bethay (2014) mengemukakan bahwa proses belajar adalah proses penyampaian pesan/materi dari pemberi pesan (guru) ke penerima pesan (peserta didik). Media pembelajaran yang menarik juga sangat diperlukan bagi siswa SD, dikarenakan sistem pembelajaran yang diberikan pada siswa SD adalah belajar sambil bermain. Media pembelajaran sangat diperlukan guru untuk membantu menyampaikan materi dalam sebuah proses pembelajaran. Proses pembelajaran yang baik haruslah memuat aspek interaktif, menyenangkan, menantang, memotivasi dan memberikan ruang lebih bagi siswa untuk dapat mengembangkan kreativitas dan kemandirian, sesuai dengan bakat dan minat siswa [1]. Meskipun guru hanya sebagai fasilitator dalam sebuah pembelajaran, dan siswa yang dituntut untuk lebih aktif, guru harus mampu membuat suasana pembelajaran yang menyenangkan untuk merangsang siswa lebih aktif dalam belajar.

Rico Fiyan Hady, Departemen Teknologi Informasi, Institut Sains dan Teknologi Terpadu Surabaya, Surabaya, Jawa Timur, Indonesia (e-mail: rico.fiyan.hady@gmail.com)

Hendrawan Armanto, Departemen Teknik Informatika, Institut Sains dan Teknologi Terpadu Surabaya, Surabaya, Jawa Timur, Indonesia (email:hendrawan@stts.edu)
Dalam pembelajaran jenjang sekolah dasar atau SD salah satu mata pelajaran yang diampu adalah IPA yang dimana bagian pada pembahasannya adalah saluran pencernaan dan saluran pernasapasan pada manusia. Mengingat pembelajaran pada jenjang SD rata-rata siswa masih berumur 9-10 tahun. Dalam mengajarkan siswa jenjang SD untuk materi saluran pencernaan dan saluran pernapasan pada tubuh manusia tentunya siswa pada umumnya akan diberikan gambaran sistem, fungsi, dan objek dari saluran pernapasan dan juga salurang pencernaan pada tubuh manusia. Dengan demikian siswa tersebut hanyalah berimajinasi tentang bentuk dari setiap organ yang terkait dalam sistem tersebut. Secara teknis guru menjelaskan materi tersebut secara lisan dan arsitektur dari materi tersebut digambarkan dengan menggunakan spidor di papan tulis, kemdian diberikan anak panah untuk menunjukkan tahapan atau setiap alurnya. Dengan media tersebut siswa akan menjadi paham, tetapi setelah beberapa lama siswa akan merasa bosan karena gambar terlihat sederhana dan hanya terlihat satu dimensi. Gambar tersebut kurang memotivasi siswa dalam belajar, sehingga proses pembelajaran dengan materi saluran pencernaan dan salurang pernapasan pada tubuh manusia ini kurang menarik dan membuat siswa merasa jenuh dan merasa kesulitan untuk menyelesaikan soalan tentang materi tersebut. Hal ini mengakibatkan hasil belajar siswa rendah.

Augmented Reality adalah teknologi yang menggabungkan benda maya dua dimensi 2D dan ataupun tiga dimensi 3D ke dalam sebuah lingkungan nyata tiga dimensi lalu memproyeksikan benda-benda maya tersebut dalam waktu nyata. Augmented Reality memiliki banyak peluang utuk terus dikembangkan, tidak ketinggal dalam pendidikan. Dari berapa hasil penelitian dalam bidang pendidikan, augmenten reality menunjukkan hasil yang positif dan membuktikan bahwa augmented reality dapat diterapkan dengan baik dalam dunia pendidikan, khususnya sebagai sebuah media pembelajaran.

Teknologi ini sangat tepat digunakan dalam pembelajaran IPA khususnya pada sistem saluran pernapasan dan saluran pencernaan pada tubuh manusia. Dengan teknologi ini berbagai bentuk dari setiap organ yang berkaitan pada sistem saluran pernapasan dan saluran pencernaan manusia akan ditampilkan dalam bentuk gambar tiga dimensi yang dapat bergerak, sehingga gambar terkesan hidup dan tidak membosankan. Animasi tiga dimensi dalam augmented reality ini dapat membantu siswa dalam memahami materi yang diberikan oleh pendidik, seperti proses awal sampai akhir seperti pada sistem saluran pernapasan mulai dari oksigen masuk kehidung sampai dihembuskan kembali dari hidung menjadi karbondioksida begitu juga pada saluran pencernaan manusia mulai dari makanan yang masuk dari mulut sampai menjadi kotoran dan dikeluarkan dari dubur akan lebih jelas jika ditampilkan 
dengan teknologi augmented reality karena alur dan tahapannya dibuat bergerak. Selain itu semua organ yang berkesinambungan dalam sistem tersebut dapat akan terlihat nyata dihadapan kita. Berdasarkan uraian diatas penelitian ini dilakukan dengan tujuan yang ingin dicapai, yaitu untuk mengetahui pengaruh media pembelajaran berbasis augmented reality terhadap peningkatan hasil belajar siswa tingkat SD pada kelas VI khususnya untuk mata pelajaran IPA dengan materi sistem saluran pencernaan dan saluran pernapasan pada tubuh manusia.

\section{PENELITIAN TERKAIT}

Penelitian yang dilakukan oleh Cheng-Ping Chen dan Chang-Wha Wa (2015) yang berjudul The Effect of learning style on Mobile Augmented-Reality Facilited English Vocabulary Learning. [2]Dalam tulisannya mereka menjelaskan bahwa mereka merancang sebuah model pembelajaran baru dalam belajar berbahasa Inggris. Dengan model pembelajaran seperti ini akan membuat siswa untuk dapat benar-benar melihat, menyentuh, dan berinteraksi dengan vocabulary yang mereka pelajari. Dengan bermodalkan internet dan smartphone yang berkamera siswa akan mengetahui sama benda dalam bahasa inggris beserta dengan ejaan inggrisnya apabila kamera pada smartphone tersebut disorotkan pada suatu benda di sekitar kita. Dalam implementasinya penulis membuat suatu permainan dalam belajar berbahasa inggris. Pertama yang harus dilakukan adalah membagi menjadi beberapa tim. Lalu tahapan dalam permainan ini yaitu, 1) mereka membuat petunjuk untuk item pertama. 2) mereka akan mendapat informasi nama dan cara mengeja item tersebut dalam bahasa inggris jika menemukan item yang sesuai dengan petunjuk. 3) lalu mereka harus melakukan tangkap layar dan menirukan pengucapan item tersebut dalam bahasa dengan baik dan benar untuk mendapatkan item selanjutnya.

Penelitian yang dilakukan oleh Malek El Kouzi, Abdihakim Mao, dan Diego Zambrano (2019) yang berjudul An Educational Augmented Reality Application for Elementary School Students Focusing on the Human Skeletal System. Adalah sebuah penelitian yang dilakukan pada jenjang Sekolah Dasar yang berfokus pada sistem gerak pada tulang manusia [3]. Penulis mempaparkan bahwa partisipan pada pembelajarannya adalah siswa yang berumur 10 dan 11 pada tingkatan kelas 5 di Sekolah Dasar. Total siswa pada kelas tersebut adalah 30 siswa dengan 1 orang guru. Secara garis besar konsep AR yang mereka buat mengikuti buku pelajaran yang sedang siswa pelajari yang dimana gambar sekletal 2D yang disebut dengan marker nantinya disorot dengan menggunakan tablet dan akan muncul diatas gambar sekletal 2D tadi tetapi dalam bentuk 3D. Peserta didik dapat merotasi gambar 3D tersebut dengan cara merotasikan buku mereka sehingga akan nampak bagian sisi lain dari gambar 3D skeletal itu sendiri. Pada jurnalnya penulis mengatakan bahwa mereka mempunyai 5 contoh gambar tulang yang dapat di interaksikan dengan siswa. Lima gambar tulang yang dimaksud meliputi, tulang kepala manusia, tulang selangka, tulang rusuk, tulang paha, dan tulang pinggang.

Penelitian yang dilakukan oleh Bambang Cahyono, Muhammad Bambang Firdaus, dan Edy Budiman (2018) yang berjudul Augmented Reality Applied to Geometry Education. Penulis memaparkan bahwa pelajaran matematika adalah mata pelajaran yang rata-rata tidak disukai oleh anak kecil maka dari itu perlu untuk membuat cara belajara dengan model lain yaitu dengan bentuk 3D sehingga siswa dapat membangun apa yang mereka inginkan dari pengalaman yang mereka miliki serta dapat berinteraksi [4]. Tidak hanya berimajinasi atas bangunan geometri yang sudah di gambarkan oleh gurunya. Dalam implementasinya penulis menggunakan strategi Multimedia Development Life Cycle (MDLC) yang tahapan ini dibagi menjadi 5 yaitu, Concept, Material Collecting, Assembly, Testing, Distribution

Penelitian yang dilakukan oleh Mohammad Fahim Hossain, Sudipta Barman, AKM Bahalul Haque (2019) adalah penelitian yang dilakukan di Bangladesh yang dimana pada setiap hari siswa diharuskan belajar dua atau lebih bahasa yaitu Bengali dan juga Bahasa Inggris [5]. Mereka harus mengenal 11 huruf vokal dan juga 39 konsonan atau huruf mati pada bahasa Bengali dan pada Bahasa Inggris terdapat 26 huruf dan simbol - simbol yang berbeda pada setiap bahasa. Jadi total yang harus dihafal adalah 76 simbol yang berbeda. Hal ini tentunya cukup menyulitkan mereka untuk menghafal satu persatu setiap simbol yang ada sehingga akan timbul rasa bosan. Dan dari sini seorang guru mengerti bahwa proses pembelajaran haruslah kreatif dan interaktif. Kita semua tahu bahwa anak kecil jaman sekarang mereka terlahir dengan smartphone yang selalu ada di tangan mereka yang artinya generasi muda mayoritas lebih paham mengenai cara menggunakan smartphone dan mereka menggunakan ini sebagai salah satu sumber belajar selain buku. Dengan begitu penulis memberikan solusi sebuah Augmented Reality (AR) yang berada pada genggaman. Sebuah buku dengan teknologi Augmented Reality (AR) akan mereka butuhkan dalam belajar. Buku ini akan penuh dengan visualisasi dan suara yang tampak nyata dengan model-model 3D buah dan juga semua huruf dari kedua bahasa. Pada setiap model 3D juga dapat di putar untuk dapat mengetahui setiap sisinya sehingga hal ini akan menarik.

Penelitian yang dilakukan oleh Carolina Mateo dan Heriot Watt (2018) mereka menceritakan bahwa untuk mendapatkan level pemahaman yang tinggi dalam memahami sebuah konsep abstrak maka dibutuhkan visualisasi dalam bentuk objek 3D dan manipulasi yang kompleks secara teori dari segi matematika sebagai contoh adalah tentang electromagnetic (EM) [6]. Sebuah proyek contoh dalam pengembangan tentang elctromagnetic tentunya membutuhkan itu demi tercapainya proyek yang baik dengan finishing sesuai sasaran yang sudah direncanakan. Siswa yang belajar dalam bidang electromagnetic (EM) tentunya membutuhkan fokus yang tinggi khususnya bagi siswa pada tahun ke-3 dimana mereka membutuhkan level pemahaman yang tinggi. Untuk mendapatkan itu maka dibuat sebuah simulasi 3D dengan teknologi Augmented Reality (AR) sehingga dapat memvisualisasikan dan meningkatkan pemahaman siswa mengenai bidang yang dimaksud. 


\section{AUGMENTED REALITY}

Augmented Reality (AR) dapat diartikan sebagai teknologi yang menggabungkan atau mencitrakan antara benda maya dua dimensi atau tiga dimensi kedalam sebuah lingkungan nyata tiga dimensi lalu memproyeksikan benda maya tersebut secara real-time. Untuk mencritrakan gambar tiga dimensi tersebut, sistem Augmented Reality terlebih dahulu harus melakukan penglihatan atau vision terhadap lingkungan yang akan dicitrakan objek virtual, kemudian dilakukanlah proses tracking terhadap image target dan menentukan letak citra objek virtual tersebut. Kemudian objek tersebut akan dikenali, atau dianalisis. Setelah dikenali dan di analisis posisi dan orientasinya, maka komputer akan melakukan proses pencitraan objek tersebut, dan ditampilkan pada perlengkapan display [7]. Proses tracking pada AR merupakan gambaran singkat tentang proses kerja AR. Proses dimulai dari pengambilan gambar marker dengan kamera. Kemudian masuk ke dalam proses tracking (pelacakan atau registrasi marker) yang meliputi : tresholding, marker detection dan proses render menggabungkan gambar asli dan komponen virtual menggunakan perhitungan pose dan orientasi marker. Hasil keluaran pelacakan marker ditampilkan pada layar komputer atau smartphone.

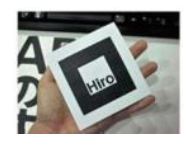
Input image

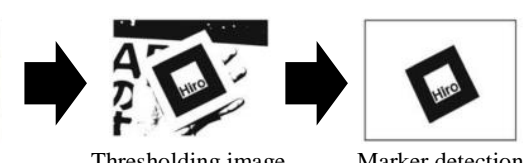

Thresholding image Marker detection

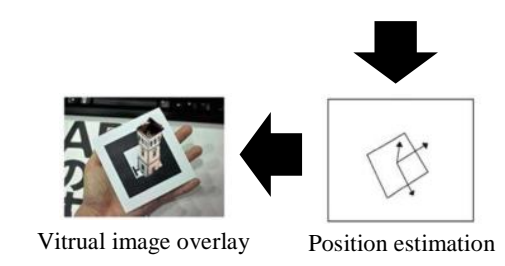

Gambar 1. Proses tracking AR

(Nanang, 2018)

IV. MARKER

Merupakan sebuah penanda khusus yang memiliki pola tertentu yang akan dikenali oleh kamera, sehingga saat kamera mendeteksi marker maka objek 3 dimensi dapat ditampilkan. Augmented Reality dapat dikategorikan menjadi dua, berdasarkan ada atau tidaknya marker yaitu menggunakan marker based tracking dan tanpa marker (markless). Marker based tracking dimana komputer akan mengenali posisi dan orientasi marker dan meciptakan dunia virtual atau 3 dimendis yaitu titik $(0,0,0)$ dan 3 sumbu yaitu X, Y, Z [8]. Marker based tracking dapat merupakan berupa foto sebuah objek nyata atau gambar buatan dengan pola unik. Markless merupakan sebuah metode pelacaan (tracking) dimana AR menggunakan objek di dunia nyata sebagai marker atau tanpa menggunakan marker buatan.

Marker atau juga bisa disebut sebagai image target memiliki kriteria untuk dapat dilacak oleh sistem AR yang meliputi : a. fitur gambarnya kaya (polanya unik) misal gambar pemandangan, gambar sekumpulan orang, kolase dan lain sebagainya.

b. Kontrasnya bagus, gelap dan terangnya jelas

c. Tidak ada pengulangan pola, misal lapangan rumput, kotak-kotak

d. Grafik warnanya 8 atau 24 bit format PNG atau JPG, ukurannya kurang dari 2 MB JPGs haruslah RGB atau grayscale (bukan CMYK)

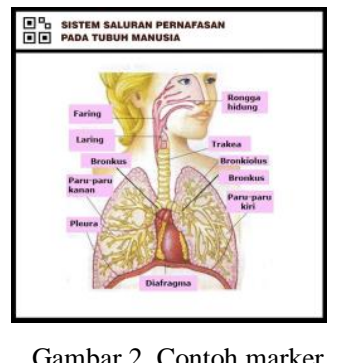

\section{METODE PENELITIAN}

Metode pengujian digunakan untuk mengukur tingkat perkembangan dan pengenalan serta mengingat siswa sebelum dan setelah pembelajaran dengan menggunakan model AR ini. Jenis pengujian berupa pre-test, post-test, dan kuisoner.

Proses pengujian dengan pre-test dan post-test dilakukan untuk mengetahui perbedaan dari sebelum dan sesudah pembelajaran dengan menggunakan model AR ini. Jenis soal yang diberikan pada pre-test dan post-test berupa soal uji pada umumnya

\section{A. Soal Pre-Test}

Tujuan dari pre-test untuk mengetahui tingkat kemampuan pemahaman siswa terhadap materi sistem saluran pernapasan dan sistem saluran pencernaan pada tubuh manusia sebelum diberikan model pembelajaran berbasis Augmented Reality. Dan hasil jawaban dari pre-test nantinya akan dijadikan hasil perbandingan dari hasil jawaban post-test

\section{B. Soal Post-Test}

Merupakan soalan yang diberikan kepada peserta didik ketika sudah di bagi menjadi dua kelompok yaitu kelompok eksperimen dan kelompok konvensional yang dimana pembelajaran antar kelom tersebut adalah berbeda. Pada kelompok eksperimen menggunakan pembelajaran berbasis Augmented Reality. Pada kelompok konvensional menggunakan pembelajaran seperti biasa yang sudah dilakukan sehari-hari pada kelas tersebut. Tujuan dari memberikan soalan post-test ini adalah untuk mengetahui pengukuran tingkat kemampuan dan pemahaman siswa terhadap perbedaan materi yang telah ditentukan. Dan hasil dari soalan post-testi ini akan disandingkan dengan hasil dari soalan pre-test.

\section{Metode Pembelajaran}

Secara teknis pada metode pembelajaran ini seluruh siswa dengan jumlah 50 siswa akan dibagi menjadi dua kelompok yaitu kelompok eksperimen dan kelompok konvensional yang dimana setiap kelompok terdiri dari 25 orang. 
Kelompok eksperimen akan menerima pembelajaran dengan menggunakan media pembelajaran Augmented Reality (AR) sedangkan Kelompok Konvensional akan menerima pembelajaran secara konvensional sebagaimana guru di sekolah tersebut memberikan materi terhadap siswanya.

\section{Quiz}

Pada kelompok eksperimen akan terdapat quiz yang dimana pada quiz tersebut terdapat tiga tingkatan yaitu mudah, sedang, sulit. Pada implentasinya quiz ini terdapat menu tersendiri yang dimana setelah pembelajaran mengenai alur dari setiap sistem dan juga mengenal bentuk serta nama organ maka user akan dihadapkan pada menu quiz untuk melatih daya ingat dari pembelajaran sebelumnya. Adapun ruang lingkup quiz pada masingmasing tingkatannya adalah sebagai berikut:

a. Tingkatan mudah

Pada tingkatan ini user atau siswa akan dihadapkan dengan pertanyaan-pertanyaan mengenai nama-nama organ yang berperan pada setiap alurnya.

b. Tingkatan sedang

Untuk pertanyaan quiz pada tingkatan sedang ini user atau siswa akan dihadapkan dengan pertanyaanpertanyaan dalam urutan organ pada setiap sistemnya.

c. Tingkatan sulit

Pada tingkatan sulit ini pertanyaan-pertanyaan yang akan muncul adalah tentang fungsi dari setiap organ sesuai dengan penjelasan dalam animasi

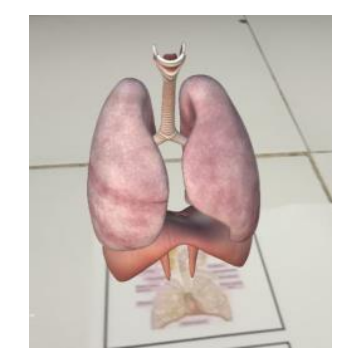

Gambar 3. Diatas marker ada model organ tubuh manusia

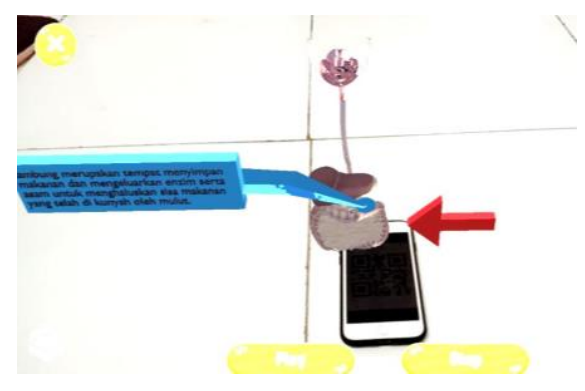

Gambar 4. Animasi alur sistem pencernaan Pada tubuh manusia
VI. HASIL

Dengan metode yang sudah dijelaskan dalam melakukan penelitian ini maka hasil yang dicapai adalah berupa nilai siswa ketika pre-test dan post-test yang dimana hasil tersebut disandingkan untuk mengetahui signifikansi pengaruh media pembelajaran dengan menggunakan Augmented Reality(AR) di jenjang sekolah dasar khususnya pada materi sistem saluran pernpasan dan sistem saluran pencernaan pada tubuh manusia. Pengelolaan data analisis statitik untuk mengukur signifikansi antara hasil pre-test dan post-test menggunakan ANOVA (Analysis of Variance). Hasil hitung dari Anova ini yang dimana sebagai acuaan adalah $F$ hitung $(F)$ dan $F$ Tabel $(F$ crit) apabila $F$ hitung lebih kecil dari pada $F$ tabel maka media pembelajaran ini tidak berpengaruh terhadap hasil belajar siswa, sebaliknya apabila $F$ hitung lebih besar dari pada $F$ tabel maka media pembelajaran ini berpengaruh terhadap hasil belajar siswa. dapat dilihat pada Tabel 3.
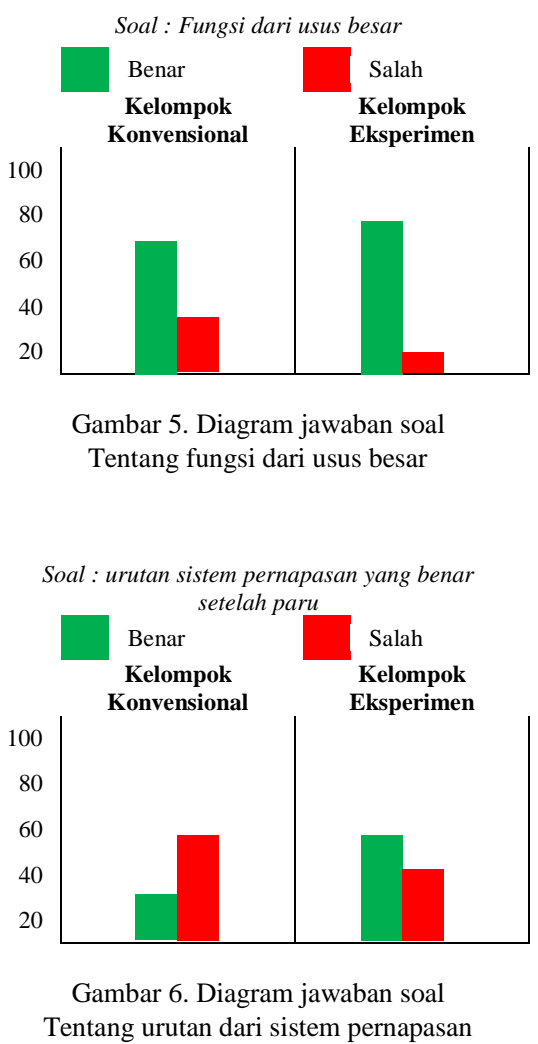

Berdasarkan hasil kuisoner tentang aplikasi yang sudah digunakan kepada peserta didik yang untuk mengetahui kelayakannya, menganalisa hasil kuisoner tersebut dengan acuan persentase dan didapatkan data sebagai berikut :

Tabel 1. Konversi hasil kegunaan sistem

\begin{tabular}{ccl} 
No. & Persentase & \multicolumn{1}{c}{ Interpretasi } \\
\hline 1 & $0 \%-20 \%$ & Sangat Tidak Layak \\
2 & $21 \%-40 \%$ & Tidak Layak \\
3 & $41 \%-60 \%$ & Cukup Layak \\
4 & $61 \%-80 \%$ & Layak \\
5 & $81 \%-100 \%$ & Sangat Layak \\
\hline
\end{tabular}


Tabel 2.

Hasil kuisoner uji kelayakan aplikasi

\begin{tabular}{lcl}
\hline \multicolumn{1}{c}{ Pertanyaan } & Persentase & \multicolumn{1}{c}{ Uraian } \\
\hline Aplikasi mudah digunakan & 80 & Layak \\
Suka bermain dengan AR & 76 & Layak \\
Membantu dalam & 64 & Layak \\
pembelajaran & 76 & Layak \\
Tertarik AR kedepannya & 60 & Cukup layak \\
Membantu dalam visualisasi & & \\
\hline
\end{tabular}

Tabel 3. Hitung hasil signifikansi menggunakan ANNOVA

\section{SUMMARY}

\begin{tabular}{crrrr} 
Groups & Count & Sum & Average & Variance \\
\hline pre-test & 25 & 1795 & 71,8 & 42,66667 \\
post-test & 25 & 1950 & 78 & 16,75 \\
\hline
\end{tabular}

\begin{tabular}{lrrrrrr} 
ANOVA & & & & & & \\
\hline $\begin{array}{l}\text { Source of } \\
\text { Variation }\end{array}$ & \multicolumn{1}{c}{ SS } & \multicolumn{1}{c}{ df } & \multicolumn{1}{c}{ MS } & \multicolumn{1}{c}{$F$} & P-value & Fcrit \\
\hline $\begin{array}{l}\text { Between } \\
\text { Groups }\end{array}$ & 480,5 & 1 & 480,5 & 16,17391 & 0,000204 & 4,042652 \\
$\begin{array}{l}\text { Within } \\
\text { Groups }\end{array}$ & 1426 & 48 & 29,70833 & & & \\
& & & & & & \\
Total & 1906,5 & 49 & & & & \\
\hline
\end{tabular}

\section{KESIMPULAN}

Berdasarkan penelitian yang telah dilakukan dengan melakukan implementasi teknologi Augmented Reality (AR) terhadap pembelajaran pada jenjang sekolah dasar khususnya materi sistem saluran pernapasan dan sistem saluran pencernaan pada tubuh manusia dapat mempengaruhi motivasi dan hasil bealajar peserta didik.

Penelitian masa mendatang akan dikembangkan lebih jauh pada materi pembelajaran yang lain atau pada jenjang sekolah yang lebih tinggi misalnya pada jenjang sekolah menengah pertama atau jenjang sekolah menengah atas yang mencangkup materi lebih luas dan mendalam

\section{DAFTAR PUSTAKA}

[1] I. Mustaqim, "Pengembangan media pembelajaran berbasis augmented reality,” J. Edukasi Elektro, vol. 1, no. 1, 2017.

[2] C. Shao, G. L. Ciampaglia, O. Varol, K. C. Yang, A. Flammini, and F. Menczer, "The spread of low-credibility content by social bots," Nat. Commun., vol. 9, no. 1, 2018, doi: 10.1038/s41467018-06930-7.

[3] M. El Kouzi, A. Mao, and D. Zambrano, "An educational augmented reality application for elementary school students focusing on the human skeletal system," in 2019 IEEE Conference on Virtual Reality and $3 D$ User Interfaces (VR), 2019, pp. 1594-1599.

[4] B. Cahyono, M. B. Firdaus, E. Budiman, and M. Wati, "Augmented reality applied to geometry education," in 2018 2nd East Indonesia Conference on Computer and Information Technology (EIConCIT), 2018, pp. 299-303.

[5] M. F. Hossain, S. Barman, and A. K. M. B. Haque, "Augmented Reality for Education; AR Children's Book," in TENCON 20192019 IEEE Region 10 Conference (TENCON), 2019, pp. 2568 2571.

[6] C. Mateo-Segura, "A new Augmented-Reality platform for Electromagnetic Education," in 2018 International Conference on Electromagnetics in Advanced Applications (ICEAA), 2018, pp. $174-177$.

[7] C. Juan, F. Beatrice, and J. Cano, "An augmented reality system for learning the interior of the human body," in 2008 Eighth IEEE
International Conference on Advanced Learning Technologies, 2008, pp. 186-188.

[8] L. Chien-Yu, J.-T. Chao, and H.-S. Wei, "Augmented realitybased assistive technology for handicapped children," in 2010 International Symposium on Computer, Communication, Control and Automation (3CA), 2010, vol. 1, pp. 61-64. 